\title{
Morpho-physiological characteristics of Jaffa orange trees (Citrus sinensis L.) in response to soil water deficit
}

\author{
Caroline Farias Barreto ${ }^{1 *}$, Renan Ricardo Zandoná ${ }^{1}$, Cleber Maus Alberto ${ }^{2}$, Juan Saavedra del \\ Aguila $^{3}$, Enio Júnior Seidel ${ }^{4}$ \\ ${ }^{1}$ Universidade Federal de Pelotas, Capão do Leão, RS, Brasil \\ ${ }^{2}$ Universidade Federal do Pampa, Campus Itaqui, Itaqui, RS, Brasil \\ ${ }^{3}$ Universidade Federal do Pampa Campus Dom Pedrito, Dom Pedrito, RS, Brasil \\ ${ }^{4}$ Universidade Federal de Santa Maria, Departamento de Estatística, Santa Maria, RS, Brasil
}

*Corresponding author: carol_fariasb@hotmail.com

\begin{abstract}
Since water is fundamental to plants, any restriction may affect growth, development and production of crops. This study aimed at evaluating leaf growth, transpiration and stomatal conductance of orange trees cv. Jaffa orange trees (Citrus sinensis L.) regarding their fraction of transpirable soil water when they encountered water deficit. The experiment was carried out in a greenhouse and one plant per pot. The experimental design was a completely randomized design with two water conditions (with and without water deficit) for twenty days, with fifteen replications per treatment. Relative transpiration, relative leaf growth, stomatal conductance of water vapor and leaf transpiration were evaluated. Analysis of variance and adjustment of logistic regression were carried out by the R Program. Plants were submitted to irrigation had higher transpiration rates and stomatal conductance than non-irrigated plants for twenty days. In orange trees, the fraction of water which was available in the soil and critical for transpiration was 0.90 , whereas for leaf growth, it was 0.65 . We concluded that this orange tree is resistant to water deficiency due to reduction of transpiration before leaf growth stage to better manage the available water in the soil.
\end{abstract}

Keywords: Citrus sinensis L.; irrigation management; leaf growth; stomatal conductance; transpiration. Abbreviations: FTSW_Fraction of transpirable soil water; TR_relative transpiration; RLG_relative leaf growth.

\section{Introduction}

In Brazil, most citrus crops have been grown in areas, where there is irregular distribution of rain, long periods of water deficit and high temperatures. Such conditions lead to water deficit which affects the growth and development of citrus crops (Soares et al., 2015). Water deficit has become one of the main factors that limit crop cultivation due to the occurrence of high rates of evapotranspiration (Nascimento et al., 2012), interference in stomatal closure, reduction in photosynthesis and transpiration (Portes et al., 2006), besides decrease in production.

Due to sustainability concerns and increased water shortage, irrigation water needs to be optimized nowadays. As a result, studies aiming at determining how much water every fruit species needs must be carried out. Regarding orange trees, strategies have been developed to improve efficiency in water use without harming plant growth (Carr, 2012; Elsayed-Farag and Melga, 2015). Stress resulting from water deficit, is an important environmental factor that affects the physiological parameters that determine plant growth and development (Soares et al., 2015), which can increase as a result of weather changes (Centritto et al., 2011).

Knowledge of the relation among soil's water deficit and plant transpiration and growth is effective to better understand responses of crops to the water deficit (Lago et al., 2012; Brilli el al., 2013; Kelling et al., 2015). Studies of plant-water relations and interactions due to water deficit in morphophysiological processes are highly important (Soares et al., 2015). Therefore, knowledge of the water consumption in crops contributes to understand the behavior of related physiological processes and their consequences (Tómas el at., 2014).

In order to evaluate crop behavior towards water deficit, a parameter that can be used is the fraction of transpirable soil water (FTSW). It takes the amount of soil water used by the plant for transpiration into account. It varies according to the soil water content ( Brilli el al., 2013; Kelling et al., 2015). Lago et al. (2012) stated that the FTSW may be the best indicator of the actual amount of soil water which may be extracted by plants for transpiration. The FTSW that begins stomatal closure (critical FTSW) is a parameter that may be used as an indicator of physiological changes resulting from water deficit (Jyostna et al., 2009).

Two stages are considered to determine the FTSW, one occurs when water is readily available for the plant in the soil and there is maximum transpiration. The other stage occurs when water that is available in the soil gets scarce and leads to reduction in stomatal conductance and transpiration to preserve the water status (Bindi et al., 2005; Martins et al., 2008). Even though, there are some studies of annual species (Sinclair and Ludlow, 1986; Davatgar et al., 2009; Jyostna et al., 2009; Kelling et al., 2015). A few studies have focused 
the FTSW of perennial species to understand responses to water deficit.

Concerning responses to soil water deficit, there is little information in the literature. It refers to the responses that plants give to the water potential in the soil (Farias et al., 2012). However, further studies on responses of plants to water deficit are needed, mainly by the FTSW method, because it is considered the best indicator of the actual amount of water which is available for plant transpiration (Lago et al., 2012). Therefore, it is important to check how orange trees behave in water stress situations by the FTSW method, so as to mitigate negative impacts on their cultivation. This study aimed at evaluating leaf growth, transpiration and stomatal conductance of orange trees trees cv. Jaffa orange trees (Citrus sinensis L.) regarding their fraction of transpirable soil water when they exposed to the water deficit.

\section{Results and discussion}

\section{Transpiration rate and stomatal conductance of water vapor}

The orange trees exhibited higher transpiration rates and average stomatal conductance than non-irrigated plants during twenty days, when they were submitted to irrigation (Table 1). In water deficit conditions, plants decrease their stomatal conductance to restrict and limit water loss (Taiz and Zeiger, 2013).

In irrigated plants, the transpiration rate on the maximum leaf occurred on the first day of the experiment $\left(1.43 \mathrm{mmol} \mathrm{m}^{-2} \mathrm{~s}^{-}\right.$ ${ }^{1}$ ), after pots were saturated with water for 48 hours (Fig 1A). It is worth highlighting that those plants that were irrigated daily kept their transpiration rates between 1.43 and 0.6 mmol m $\mathrm{m}^{-2} \mathrm{~s}^{-1}$ in twenty days.

Regarding plants with water deficit, the transpiration rate on the maximum leaf occurred on the first day of the experiment $\left(1.47 \mathrm{mmol} \mathrm{m}^{-2} \mathrm{~s}^{-1}\right)$ (Fig 1B). They showed that the transpiration rate decreased as a result of the number of days with no irrigation. Decrease in the processes of gas exchange, along with the leaf transpiration rate, were progressive and got closer to zero $\left(0.03 \mathrm{mmol} \mathrm{m}^{-2} \mathrm{~s}^{-1}\right)$ in the orange trees after twenty days of no irrigation. Leaf transpiration rate decreased as a result of partial stomatal closure due to the stress caused by the water deficit. It may be implied that this type of response, given by stomata of citrus crops, occurs when there is water deficit, as an adaptation which aims at saving water, because there is high resistance and waxiness on the leaves (Pereira et al., 2009).

Stomatal conductance at the implementation of the experiment was $0.08 \mathrm{~mol} \mathrm{~m}^{-1} \mathrm{~s}^{-1}$. It decreased to $0.004 \mathrm{~mol} \mathrm{~m}^{-}$ ${ }^{1} \mathrm{~s}^{-1}$ after twenty days in irrigated plants (Fig 1C). However, plants with no irrigation showed sharp decrease in stomatal conductance after nine days. It became close to zero after twenty days (Fig 1D). Gomes et al. (2004) observed that transpiration and stomatal conductance decreased after seven days of stress submitted to 2.5-year-old Pêra orange trees which had been grafted on Cravo lemon trees with water deficit.

\section{Fraction of transpirable soil water}

The more the FTSW decreased, the more both normalized variables relative transpiration (RT) and relative leaf growth (RLG) diminished. According to Sinclair and Ludlow (1986), the decrease may be described by a logistic equation. The critical FTSW of the orange tree was 0.90 (Fig 2). It was higher than the ones of fruit crops, such as grapevine cultures (Vitis vinifera L.) studied by Bindi et al. (2005) (0.35). However, this critical FTSW value for transpiration was similar to those found for eucalyptus trees, i. e., 0.90 for Eucalyptus grandis and 0.70 for E. saligna (Martins et al., 2008). The result of orange trees was also higher than the one of annual cultures, such as corn, mung beans, pigeon pea and soybean (critical FTSW was 0.40) (Sinclair and Ludlow, 1986), rice (critical FTSW was 0.46) (Davatgar et al., 2009) and peanut (critical FTSW was between 0.22 and 0.71 ) (Jyostna et al., 2009).

The high FTSW value found for orange trees may be seen as an advantage they have, by comparison with other cultures. According to Lago et al. (2011), when stomatal closure occurs before the moment in which there still is water availability, it enables the plant to undergo longer periods of water deficit. i. e., when RT begins to decrease in relation to the critical FTSW. Capacity to decrease transpiration enables plants to better manage the available water in the soil. These data not only help to manage field work so that the plant may resist water deficit longer but also enables more flexibility regarding irrigation control to irrigate fewer times with adequate water supply.

\section{Relative leaf growth}

The critical FTSW of the orange tree - 0.65 - for RLG may also be considered a high value (Fig 3). In studies of grapevine cultures, the critical FTSW was 0.35 for relative leaf growth (Bindi et al., 2005). RT was observed to decrease before RLG in relation to the FTSW. It shows that RT started to decrease to higher critical FTSW than RLG, because plants with water deficit make leaf cell walls dehydrate, decrease transpiration and cause stomatal closure, thus, mitigating growth (Taiz and Zeiger, 2013).

When a plant was submitted to water stress, almost all growth and development factors are affected, resulting in changes in anatomy and morphology and interference in metabolic reactions (Portes et al., 2006). Therefore, lack of water decreases turgor pressure, and consequently, sap flow through vessels (Taiz and Zeiger, 2013), tend to decrease cell elongation and growth and development of plants.

In fact, RT decreases before the RLG shows that plants are able to decrease water consumption. It may occur due to low stomatal aperture and lead to leaf growth retardation. Stomatal responses are closely related to the water content found in the soil, i. e., stomata respond to chemical signals which come from the roots as a result of dehydration. Roots act as sensors of water deficit in the soil. It is detected by stoma guard cells even before any water deficit may be observed in leaves, since signals of abscisic acid (ABA) are sent to the aerial part of the plant (Mattos et al., 2005). ABA is synthesized in mesophyll cells at low rates and tends to accumulate in chloroplasts and, at higher rates, in the leaf apoplast, thus, leading to stomatal closure (Taiz and Zeiger, 2013). These changes in stomatal conductance may be controlled when plants are submitted to water shortage. They may tolerate or resist variable periods of water deficit.

\section{Materials and methods}

\section{Site, plant materials and soil}

This experiment was conducted between October and November 2012 at the Universidade Federal do Pampa, in Itaqui, Rio Grande do Sul, in the south of Brazil. Local 
Table 1. Average of transpiration rate and stomatal conductance in irrigated Jaffa orange trees cultivated in a greenhouse for twenty days.

\begin{tabular}{lcc}
\hline Irrigation management of plants & $\begin{array}{c}\text { Transpiration rate } \\
\left(\mathrm{mmol} \mathrm{m} \mathrm{s}^{-2}\right)\end{array}$ & $\begin{array}{c}\text { Stomatal conductance }\left(\mathrm{mol} \mathrm{m}^{-1} \mathrm{~s}^{-1}\right) \\
\text { Irrigated }\end{array}$ \\
Non-irrigated & $0.03 \mathrm{a}$ & $0.07 \mathrm{a}$ \\
Averages followed by the same letter do not differ at 5\% probability. Mann-Whitney test. & $0.05 \mathrm{~b}$ \\
\hline
\end{tabular}
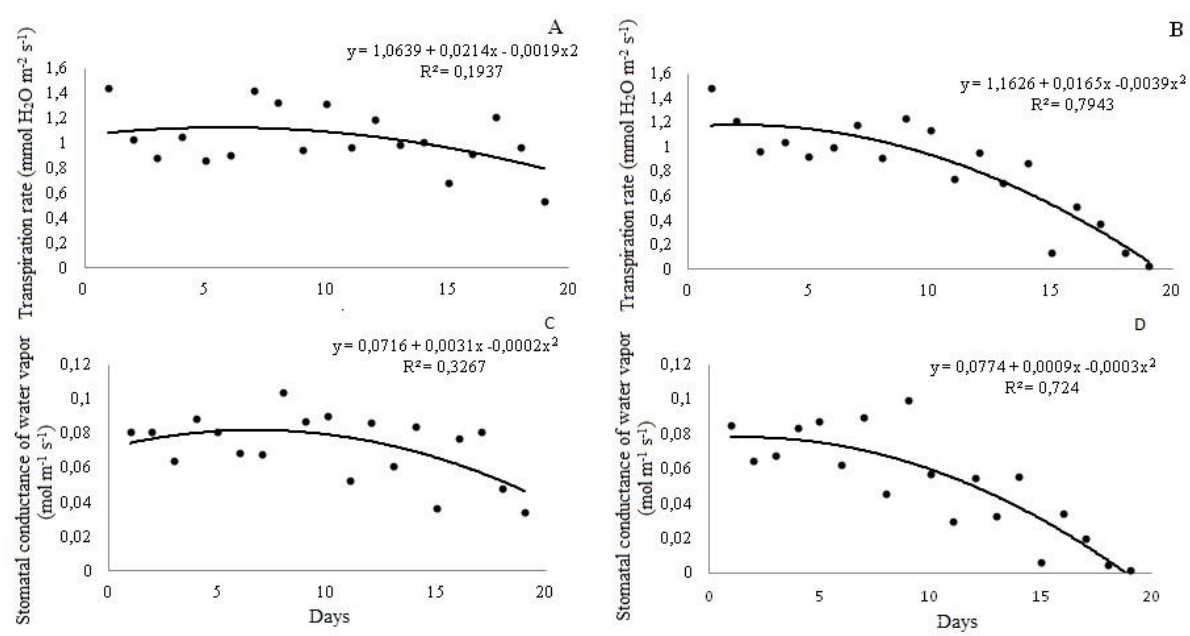

Fig 1. Transpiration rate $\left(\mathrm{mmol} \mathrm{H}_{2} \mathrm{O} \mathrm{m}^{-2} \mathrm{~s}^{-1}\right)$ in irrigated plants ${ }^{\mathrm{ns}}(\mathrm{A})$ and non-irrigated ones* $(\mathrm{B})$ and stomatal conductance of water vapor $\left(\mathrm{mol} \mathrm{m}^{-1} \mathrm{~s}^{-1}\right)$ in irrigated plants* $(\mathrm{C})$ and non-irrigated ones* $(\mathrm{D})$ of Jaffa orange trees regarding the fraction of transpirable soil water up to $10 \%$ of relative transpiration. Significant quadratic regression at $5 \%$ probability. ${ }^{\mathrm{ns}}$ Non-significant regression. F-test.

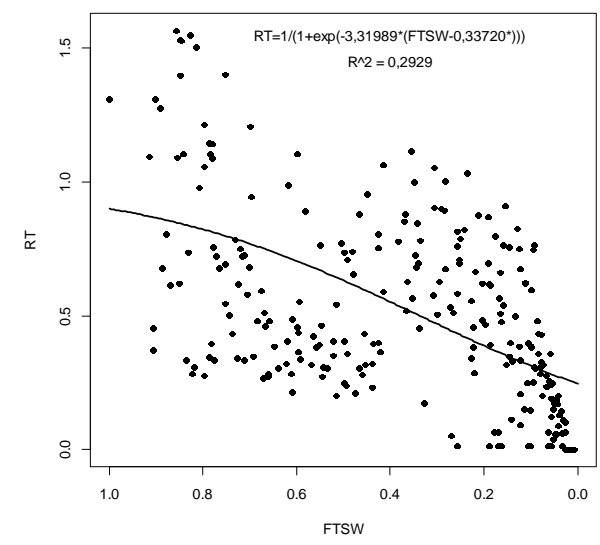

Fig 2. Normalized relative transpiration (RT) as the result of the fraction of transpirable soil water (FTSW) of Jaffa orange trees cultivated in a green house. Significant estimates at $5 \%$ probability. T-test.

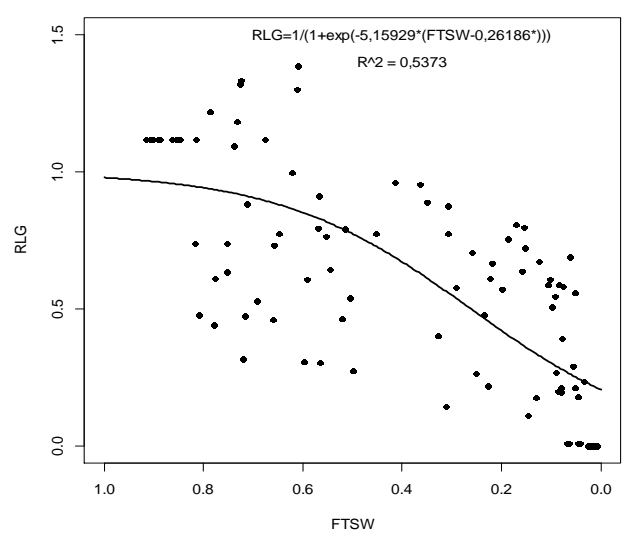

Fig 3. Normalized relative leaf growth (RLG) as the result of the fraction of transpirable soil water (FTSW) of Jaffa orange trees cultivated in a green house. Significant estimates at $5 \%$ probability. T-test. 
climate falls into category C, subtype Cfa (Subtropical Climate), in Köppen's classification, i. e., winter is cold and humid, whereas summer is moderate and dry.

The experiment used 2-year-old seedlings of Jaffa orange trees (Citrus sinensis L.) on Poncirus trifoliata rootstock. The experiment was carried out in a greenhouse, during the experiment, maximum temperatures ranged from 21 to $25^{\circ} \mathrm{C}$, minimum temperatures were between 12 to $15^{\circ} \mathrm{C}$, relative humidity varied daily between 50 and $80 \%$ and 12 hours of light a day.

The plants were placed in 8-liter pots with soil. Chemical analyses of the soil (0-20 cm depth) were as follows: $\mathrm{pH}_{(\mathrm{H} 2 \mathrm{O})}$ $=5.4, \mathrm{P}=11,4 \mathrm{mg} \mathrm{dm}^{-3}, \mathrm{~K}=43 \mathrm{mg} \mathrm{dm}{ }^{-3}, \mathrm{Ca}^{2+}=3,79$ cmolc $\mathrm{dm}^{-3}, \mathrm{Mg}^{2+}=1,5 \mathrm{cmolc} \mathrm{dm}^{-3}$, organic matter $=20 \mathrm{~g} \mathrm{~kg}^{-1}$.

\section{Irrigation treatments}

The experimental design was a completely randomized design, with two water conditions and fifteen replications per treatment: $\mathrm{T} 1=$ no water deficit (with irrigation); $\mathrm{T} 2=$ with water deficit (no irrigation). The experiment started when all pots were water-saturated and a water blade formed on the soil surface. After saturation, pots were drained for 48 hours and covered with a white plastic film to mitigate water loss through soil evaporation, ensuring that water would only be lost as a result of plant transpiration and external walls of the 8 -liter pots were painted white in order to reduce solar radiation absorption.

After drainage, initial mass of every pot was determined. Then, 15 plants were submitted to a water deficit (T2), while other 15 plants continued to be well watered to pot capacity in order to represent control plants (T1).

Masses of all pots were determined daily by an electronic scale whose capacity was $50 \mathrm{~kg}$ and precision was $5 \mathrm{~g}$. After weighing, every $\mathrm{T} 1$ pot was irrigated with the water amount lost by the plant transpiration. The applied amount of water was determined by the difference between the mass of the pot on the day it was measured and the initial mass (the mass of the pot on the day water deficit was applied), according to the methodology Sinclair and Ludlow (1986). The pots of the T2 plants were water-saturated and a water blade formed on the soil surface and after plants received no more water until the end of the experiment, for twenty days.

\section{Traits measured}

Stomatal conductance of water vapor $\left(\mathrm{mol} \mathrm{m}^{-1} \mathrm{~s}^{-1}\right)$ and transpiration rate $\left(\mathrm{mmol} \mathrm{H} \mathrm{H}_{2} \mathrm{O} \mathrm{m}^{-2} \mathrm{~s}^{-1}\right)$ were carried out on completely expanded leaves from the middle third of the plant. The analysis was conducted by a portable photosynthesis analyzer - open system LCA PRO (Analytical Development Co. Ltd, Hoddesdon, UK). Readings were carried out daily between 8 and 9 am. Data analysis was based on the comparison between relative transpiration (RT) and the fraction of transpirable soil water (FTSW) for every plant. RT was calculated by equation, which was proposed by Sinclair and Ludlow (1986), where:

$\mathrm{RT}=$ daily water loss by $\mathrm{T} 2$ plants (every pot) average of daily water loss by $\mathrm{T} 1$ plants

Daily water loss by $\mathrm{T} 2$ plants was obtained by subtracting the mass of a pot on a certain day from the mass of same pot a day before. Daily water loss by T1 plants was obtained by determining the mass of a pot on a certain day and subtracting it from the mass the same pot on a day of the beginning of the experiment (initial mass).
The fraction of transpirable soil water (FTSW) was calculated by equation proposed by Sinclair and Ludlow (1986), as follows:

$$
F T S W=\frac{M(n)-F M}{M i-F M}
$$

$\mathrm{FTSW}=\frac{\underline{\mathrm{M}}_{(\mathrm{n})}}{\mathrm{M}_{\mathrm{i}}-\mathrm{FM}}$

Where; $M_{(n)}$ is the daily mass of the pot, $M_{i}$ is the initial mass of every pot and FM is the final mass. The experiment was ended when more than half of $\mathrm{T} 2$ plants reached transpiration below $10 \%$ ( $\mathrm{RT} \leq 0.1)$. The limit $\mathrm{RT} \leq 0.1$ was chosen because, according to Sinclair and Ludlow (1986), this limit has been imposed since stomata are closed below this transpiration rate and water loss is just due to epidermal conductance.

In order to determine the total leaf area $\left(\mathrm{cm}^{2}\right)$ of every plant, the length (L) and width (W) of every leaf of Jaffa orange trees were measured by a ruler graduated in centimeters. Measurements were carried out every two days, from the beginning of the water deficit application to the end of the experiment. The product of the leaf length and width was multiplied by a correction factor $\left(\mathrm{C}_{\mathrm{f}}\right)$, in agreement with Cairo et al. (2008). Real leaf area was obtained at the end of the experiment in 30 orange tree leaves by a digital leaf area meter $\left(\mathrm{LI}-3100 \mathrm{C}^{\circledR}\right)$. The estimated leaf area of every plant was obtained by multiplying it by $\mathrm{C}_{\mathrm{f}}=0.72$.

The daily total leaf area of every plant was calculated by adding up the LA of all its leaves. Data on daily total leaf areas enabled the calculation of the daily relative leaf growth (RLG) by equation, as follows:

$\mathrm{RGL}=\frac{\text { Total leaf area of every T2 plant }}{\text { Average of leaf area of T1 plants }}$

Increase in the total leaf area of $\mathrm{T} 1$ and $\mathrm{T} 2$ plants (daily) was calculated by the difference between the total leaf area of every plant and the total leaf area of the same plant on the previous day. Both variables RT and RLG were normalized. The first normalization $(\mathrm{N})$ was carried out in agreement with Sinclair et al. (2005), in order to be kept in the interval from 0 to 1 , by the following equations:

$\mathrm{N}=\mathrm{RT}$ at $10 \%$ - value of variable on the day

$(\mathrm{RT}) \mathrm{N}=\frac{(\mathrm{RT}) 10 \%-(R T) n}{(T R) 10 \%-(R T) i}$

$(R G L) N=\frac{(\mathrm{RGL}) 10 \%-(\mathrm{RGL}) \mathrm{n}}{(\mathrm{RLG}) 10 \%-(R G L) i}$

Where; (RT or RLG) $)_{\mathrm{N}}$ is the normalized value of transpiration (RT) or relative leaf growth (RLG), RT at $10 \%$ corresponds to the value of the variable (RT or RLG) when RT reached $10 \%$ at the end of the experiment, (RT or RLG) is the value of the variable on the day and (RT or RLG) $)_{i}$ is the value of the variable on the first day of the experiment. In the second normalization of RT and RLG, all values of RT or RLG above 0.50 were separated (Sinclair and Ludlow, 1986; Martins et al., 2008).

After the second normalization, data on RT and RLG were determined as a function of the FTSW and adjusted to the logistic equation, in agreement with Lago et al. (2011):

$\mathrm{Y}=1 /\{1+\exp [-\mathrm{a}(\mathrm{X}-\mathrm{b})]\}$

Where; $\mathrm{Y}$ is the dependent variable (RT or RLG), $\mathrm{X}$ is the FTSW and "a" and "b" are empiric coefficients (Sinclair and Ludlow, 1986), estimated by nonlinear regression analysis.

\section{Statistical analysis}

Quadratic regressions were adjusted to the following variables: days and average transpiration rate; and days and 
average stomatal conductance in irrigated and non-irrigated plants. Afterwards, the Mann-Whitney test was carried out in order to compare the transpiration rate and the stomatal conductance in irrigated and non-irrigated plants. The statistical analysis of the data and the adjustment of the logistic regression were conducted by the R Program ( $\mathrm{R}$ Core Team, 2012).

\section{Conclusion}

Plants were submitted to irrigation had higher transpiration rates and stomatal conductance than non-irrigated plants for twenty days. Both the transpiration rate and the stomatal conductance of leaves of orange trees decrease as a result of the number of no-irrigation days (drought condition). In nonirrigated plants, both the transpiration rate and the stomatal conductance of leaves became close to zero after twenty days of no-irrigation. Fractions of transpirable soil water for relative transpiration and relative leaf growth of orange trees were 0.90 and 0.65 , respectively. Therefore, it is a cultivar that is able to endure long water deficit periods. Decrease in water that is available in the soil leads to decrease in relative transpiration before restricting leaf growth of orange trees and enables plants to better manage water that is available in the soil.

\section{Acknowledgement}

This research was supported the Universidade Federal do Pampa.

\section{References}

Bindi M, Bellesi S, Orlandini S, Fibbi L, Moriondo M, Sinclair T (2005) Influence of water deficit stress on leaf area development and transpiration of Sangiovese Grapevines grown in pots. Am J Enol Viticult. 56:68-72.

Brilli F, Tsonev T, Mahmood T, Velikova V, Loreto F, Centritto M (2013) Ultradian variation of isoprene emission photosynthesis, mesophyll conductance and optimum temperature sensitivity for isoprene emission in waterstressed Eucalyptus citriodora saplings. J Exp Bot. 64, 519-528.

Cairo PAR, Oliveira LEM, Mesquita AC (2008) Análise de crescimento de plantas. Vitória da Conquista: Edições UESB, 72p.

Carr MKV (2012) The water relations and irrigation requirements of citrus (Citrus spp.): a review. Exp Agric. 48, 347-377.

Centritto M, Tognetti R, Leitgeb E, Střelcová K, Cohen S (2011) Above ground processes: anticipating climate change influences. In: M Bredemeier, S Cohen, DL

Davatgar N, Neishabouri MR, Sepaskhah AR, Soltani A (2009) Physiological and morphological responses of rice (Oryza sativa L.) to varying water stress management strategies. Int J Plant Prod. 3:19-32.

Elsayed-Farag S, Melgar RC (2015) Efficiency of tree-based water status indicators at the onset of water deficit in Citrus. Hortic Environ Biote. 56:305-309.

Farias MF de, Saad JCC, Villas Bôas RL, Dantas JS (2012) Manejo da rega na cultura do crisântemo de corte cultivado em ambiente protegido. Rev de Ciências Agrárias, 35: 128-133.
Gomes MMA, Lago AMA, Medin CL, Machado EC, Machado MA (2004) Interactions between leaf water potential, stomatal conductance and abscisic acid content of orange trees submitted to drought stress. Braz J Plant Physiol. 16:155-161.

Jyostna DM, Sinclair TR, Vadez V, Krishnam UL (2009) Peanut genotypic variation in transpiration efficiency and decreased transpiration during progressive soil drying. Field Crops Res. 114:280-285.

Kelling CRS, Reichardt K, Streck NA, Lago I, Zanon AJ, Rodrigues MA (2015) Transpiração e crescimento foliar de crisântemo em função da fração de água transpirável no substrato. Pesqui Agropec Bras. 50:735-744.

Lago I, Streck NA, Bisognin DA, Souza AT, Silva MR (2011) Transpiração e crescimento foliar de plantas de mandioca em resposta ao déficit hídrico no solo. Pesqui Agropec Bras. 46:1415-1423.

Lago I, Streck NA, Zanon, AJ, Hanauer JG, Bisognin AA, Silva MR (2012) Transpiração e crescimento foliar de clones de batata em resposta à fração de água transpirável no solo. Rev Bras Cienc Solo. 36:745-754.

Nascimento AKS, Fernandes PD, Suassuna JF, Oliveira ACM, Sousa MSS, Azevedo JGN (2012) Tolerância de genótipos de citros ao estresse hídrico na fase de portaenxerto. Rev Irriga. Special edition:438-452.

Martins FB, Streck NA, Silva JC, Morais WW, Susin F, Navroski MC, Vivian MA (2008) Deficiência hídrica no solo e seu efeito sobre transpiração, crescimento e desenvolvimento de mudas de duas espécies de eucalipto. Rev Bras Cienc Solo. 32:1297-1306.

Mattos JLS, Gomide JA, Huaman CAM (2005) Crescimento de espécies do gênero Brachiaria, sob déficit hídrico, em casa de vegetação. Rev bras zootecn. 34:746-754.

Pereira AB, Villa NA, Alfaro AT (2009) Necessidades hídricas de citros e macieiras a partir da área foliar e da energia solar. Rev Bras Fruti. 31:671-679.

Portes MT, Alves TH, Souza GM (2006) Water deficit affects photosynthetic induction in Bauhinia forficata Link (Fabaceae) and Esenbeckia leiocarpa Engl. (Rutaceae) growing in understory and gap conditions. Braz J Plant Physiol. 18:491-512.

R Development Core Team. R (2012) A language and environment for statistical computing. Vienna: $\mathrm{R}$ Foundation for Statistical Computin.

Sinclair TR, Ludlow MM (1986) Influence of soil water supply on the plant water balance of four tropical grain legumes. Aust J Plant Physiol. 13:319-340.

Sinclair TR, Holbrook NM, Zwieniecki, MA (2005) Daily transpiration rates of woody species on drying soil. Tree Physiol, 25:1469-1472.

Soares LA dos A, Brito MEB, Fernandes PD, Lima GS de L, Soares Filho W dos S, Oliveira ES (2015) Crescimento de combinações copa- porta-enxerto de citros sob estresse hídrico em casa de vegetação. Rev bras eng agríc ambient. 19:211-217.

Taiz L, Zeiger E (2013) Plant physiology. 5 ed. Porto Alegre: Artmed, $918 \mathrm{p}$.

Tomás M, Medrano H, Escalona JM, Martorell S, Pou A, Ribas-Carbó M, Flexas, J (2014) Variability of water use efficiency in grapevines. Environ Exp Bot. 103:148-157. 